\title{
Watching Me, Watching You: Reflections Upon Surveillance, Gare Loch Duality and the \#UndesiredLine
}

\author{
B. D. OWENS \\ Independent Artist
}

\begin{abstract}
From my local observations, the everyday military surveillance, an ever-present panopticon, perpetuates both conscious and unconscious stress in the lives of those who endure it. In this paper I will reflect upon my experiences of a 224-mile pilgrimage that I undertook in 2018, over a period of 50 days. It was a daily walk from the front door of my house to the front door of the Faslane Nuclear Submarine Base, on the Gare Loch in Scotland. A walking performance, through which I drew an Undesired Line on the grass verge in parallel to an existing "undesired line"the perimeter fence of the Base.
\end{abstract}

Throughout the time the performance was in progress, I made an online text artwork using the Twitter hashtag \#UndesiredLine. One year later, I reactivated the \#UndesiredLine textwork in order to analyze subsequent observations and to establish a platform (and outlet) to examine the complex reality of Gare Loch "duality." I will look at the potential legacy for The Undesired Line, and how I can use the documentation: video, photos, daily journal writings, field recordings, tweets and maps.

In addition to appraising my own work, I will discuss surveillance-focused artworks by David Rokeby, Janet Cardiff and The Surveillance Camera Players. I will also consider some of the ethical challenges of interactive art, as well as the implications and limitations of "piggy-backing" an online artwork onto existing online platforms such as Twitter and Google Maps.

\section{INTRODUCTION}

2018 was the $50^{\text {th }}$ anniversary year of the Faslane Nuclear Submarine Base (also known as Her Majesty's Naval Base, Clyde or HMS Neptune). ${ }^{1}$ The Faslane Base is situated on the Gare Loch, a deep stretch of sea water that branches off the Firth of Clyde in Scotland. "The [UK] Secretary of State for Defence owns 53,522 acres of land principally around Garelochhead," which includes the Coulport nuclear weapons storage facility and the nuclear submarine base. ${ }^{2,3}$ 
My family has lived within a 16-mile radius of the Faslane Base since 1978, and for the past 18 years on the east shore of the Gare Loch near its heavily surveilled perimeter fence. ${ }^{4}$ A series of sinister events in my neighborhood led me to embark on a 50-day, 224-mile pilgrimage and multidisciplinary project, which has enabled me to reflect upon my personal experiences of surveillance in the geographical region where I live. ${ }^{5,6}$

\section{Surveillance, Art and Performance}

It is likely that the geographical region and the generation into which an individual is born may affect the variation in attitudes towards surveillance technologies and determine how consciously unnatural it feels to be surveilled. In the area of Scotland where I live, next to the UK's heavily guarded nuclear weapons cache, the overt presence of military surveillance could lead one to think that the Cold War never really ended. However, elsewhere, the post-Cold War generation has grown up in a world where police and military surveillance technologies have crept insidiously into daily life. ${ }^{7}$ In the $1990 \mathrm{~s}$, the increase of "open street" CCTV systems and "biometric technologies" in North America and Europe prompted renewed scrutiny from artists and thinkers such as David Rokeby, Janet Cardiff and activist-performers The Surveillance Camera Players. ${ }^{8}{ }^{9}$ In addition to examining my own work, in this essay I will highlight artworks, performances and writings that have informed my Gare Loch Duality and the \#UndesiredLine project work. The following examples demonstrate three aspects of surveillance that interest me; human behavior in surveilled space, being the watcher and being the watched.

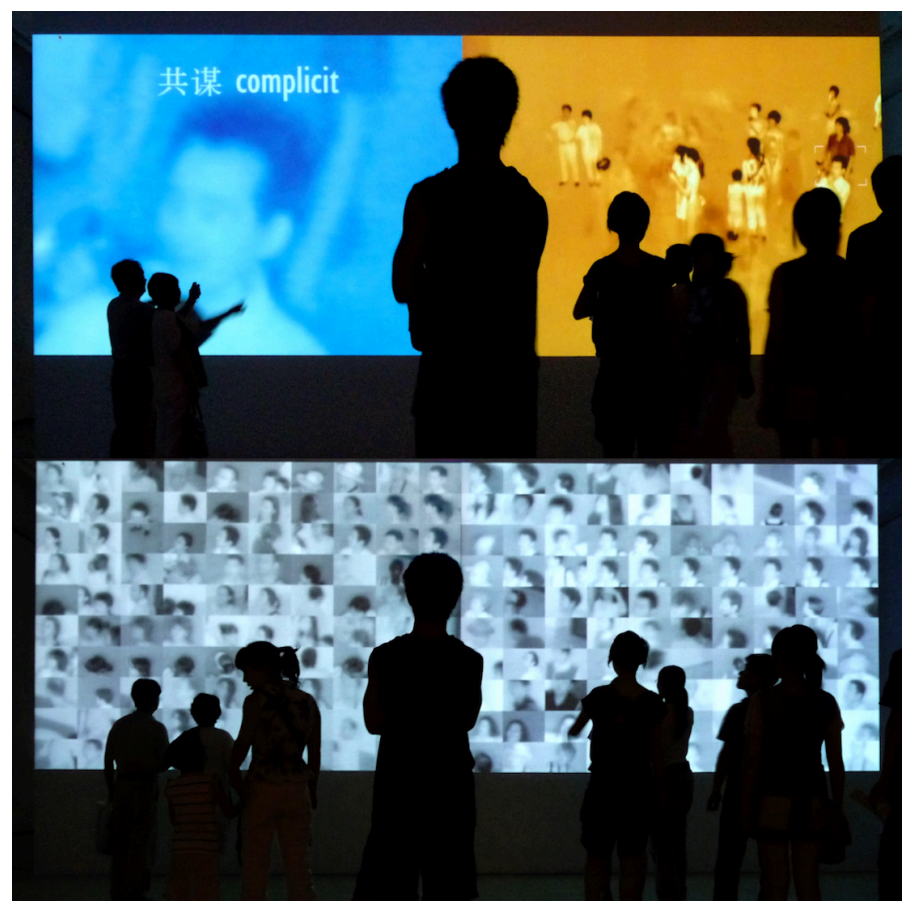

Figure 1. Taken, 2002, David Rokeby, live feed video installation, National Art Museum of China, Beijing, 2008, (C) David Rokeby. Image used with permission. 
David Rokeby's artworks have informed my understanding of the surveillance of space.

Rokeby's live feed video surveillance installation, Taken (2002), reveals how people respond to surveillance in a controlled semi-public environment. The installation recreates a facial recognition profiling system. ${ }^{10}$ On one side of the screen, the algorithm generates text adjectives that speculate character judgement on each tracked person who enters the space. ${ }^{11}$ On the other half, a transforming tableau provides an opportunity to interact and play with one's own ghost images in relation to phantom traces of other viewers. ${ }^{12}$ The screen switches every few minutes to display a matrix of the participants' mugshots. ${ }^{13}$ The Taken installation confirms Hille Koskela's assertions that surveillance changes "the nature of space."14

When analyzing his own work, in his essay "Construction of Experience: Interface as Content," Rokeby raises important ethical concerns:

"[A]rtificial experiences subtly change the way we feel, perceive, interpret, and even describe our "real" experiences.... [W] need to expand the terms of this interactive feedback loop from simply measuring functionality and effectiveness, to include an awareness of the impressions an interaction leaves on the user and the ways these impressions change the user's experience of the world." 15

Rokeby's points have prompted me to consider how viewers interact with my project work.

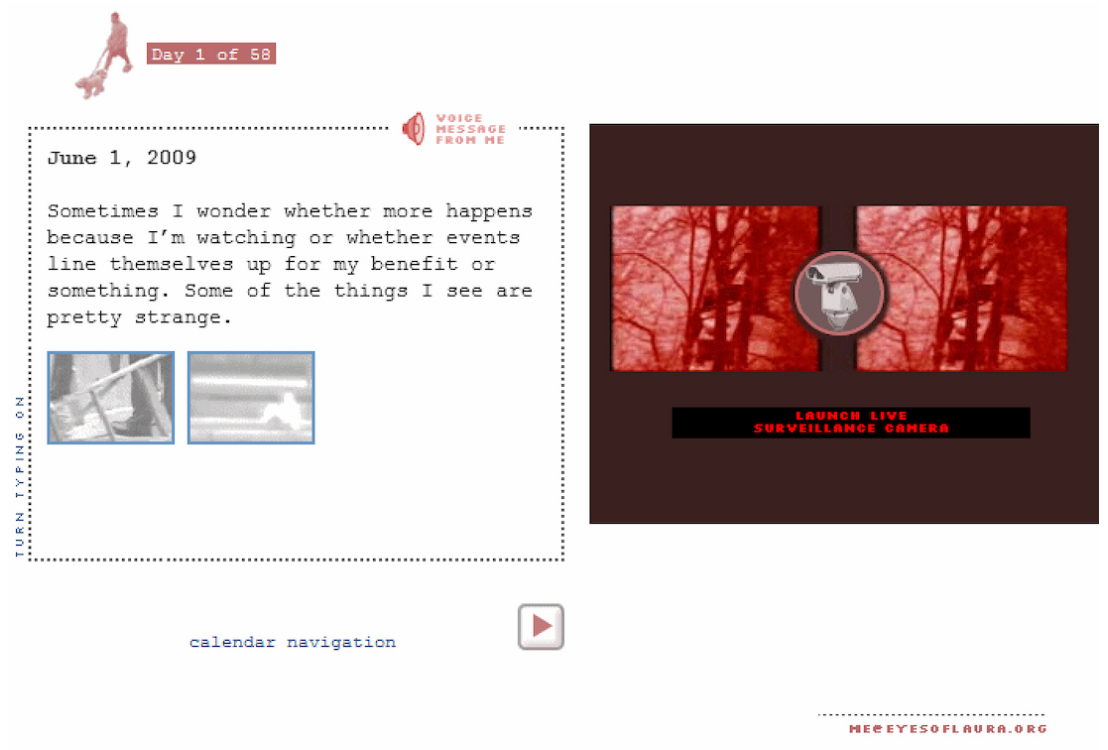

\section{Figure 2. Eyes of Laura, 2004, Janet Cardiff, website still, Vancouver Art Gallery Vancouver, British Columbia $@$ Janet Cardiff. (Image used with permission.)}

While I have been developing the Gare Loch Duality and the \#UndesiredLine project, I have been thinking about the versatility of an online interactive surveillance artwork by Janet Cardiff. The Eyes of Laura (2004) was commissioned and hosted by the Vancouver Art Gallery. ${ }^{16}$ I was 
fortunate to have had the opportunity to interact with it online before it was archived. Eyes of Laura was a fictional narrative; a 253-day blog-journal from the perspective of a security guard called Laura. ${ }^{17}$ It incorporated text, audio and staged video surveillance footage of characters outside the gallery. ${ }^{18}$ One of the interactive elements gave the viewer the option to control a livefeed camera attached to the outside of Vancouver Art Gallery and to surveil real-time activities in Robson Square. ${ }^{19}$ I was drawn to the intuitive, accessible, multifaceted hybridity of this artwork that enticed the viewer to become immersed in the mystery of the narrative. In addition, by enabling the viewer to have the option to control the livestream surveillance camera and see the same cityscape as Laura, (as if through her "eyes"), the viewer could become the watcher of strangers.

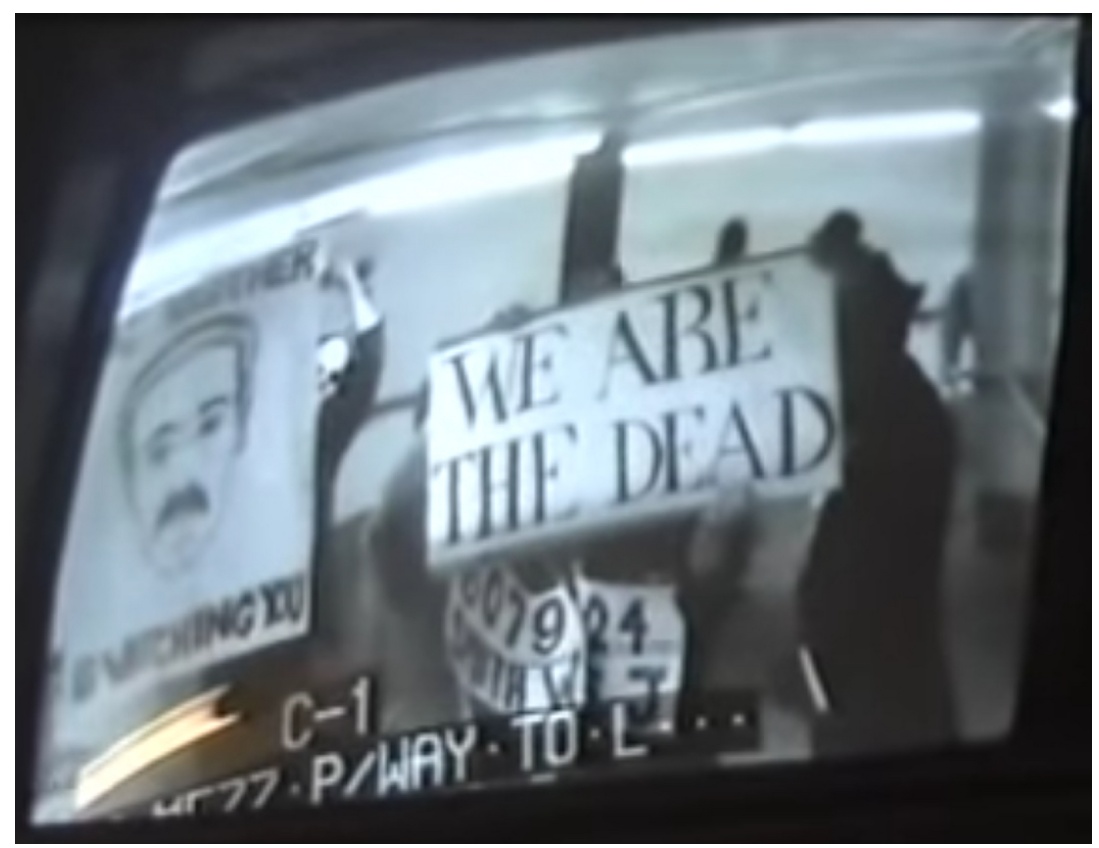

\section{Figure 3. 1984, 1998, Surveillance Camera Players, performance video still (C) Surveillance Camera Players. (Image used with permission.)}

Unlike David Rokeby and Janet Cardiff, the Surveillance Camera Players did not define themselves as artists; they were activist street-theatre performers. ${ }^{20}$ From 1996-2006, they led CCTV tours in New York City and performed plays to audiences of security guards and police crews behind the cameras. ${ }^{21}$ They documented their production of George Orwell's 1984 by shooting video of the police-camera CCTV monitors on the NYC subway platform, where the play took place. ${ }^{22}$ Like the Surveillance Camera Players, the primary audience for my Undesired Line walking performance (Spring, 2018) was the crew monitoring the Ministry of Defence (MoD) surveillance cameras along the sightline of the performance path. 


\section{Gare Loch Panopticon and the \#UndesiredLine}

Much of the early literature written on "surveillance society" references Michel Foucault's analysis of Jeremy Bentham's panopticon prison design; a prison where the guards can see the prisoners, but the prisoners cannot see the guards. ${ }^{23}$ Inside the panopticon, the prisoners assume they are being observed at all times, and therefore they self-modify their behavior. ${ }^{24,}{ }^{25}$ In the Gare Loch and Loch Long region in the West of Scotland, the panopticon analogy remains relevant, particularly regarding self-regulation and self-censorship. According to Joshua Franco (a senior research advisor and deputy director of Amnesty Tech at Amnesty International), "[i]f you feel you're being watched, you self-police, and this pushes people out of the public space."26 Since Edward Snowden's “disclosures" in 2013, in addition to the visible surveillance techniques, in the Gare Loch and Loch Long area, one can assume that all electronic communications and web searches are being monitored. ${ }^{27}$ Taking these factors into account, there are valid reasons to be concerned about the impacts of surveillance on the psychological well-being of individuals and communities. In their article "Experiencing the 'Surveillance Society,"” psychologists Darren Ellis, Dave Harper and Ian Tucker raise concerns that "[t]he spread of surveillance across public and private space presents the potential for people's sense of self and identity to be shaped by surveillance. ${ }^{28}$

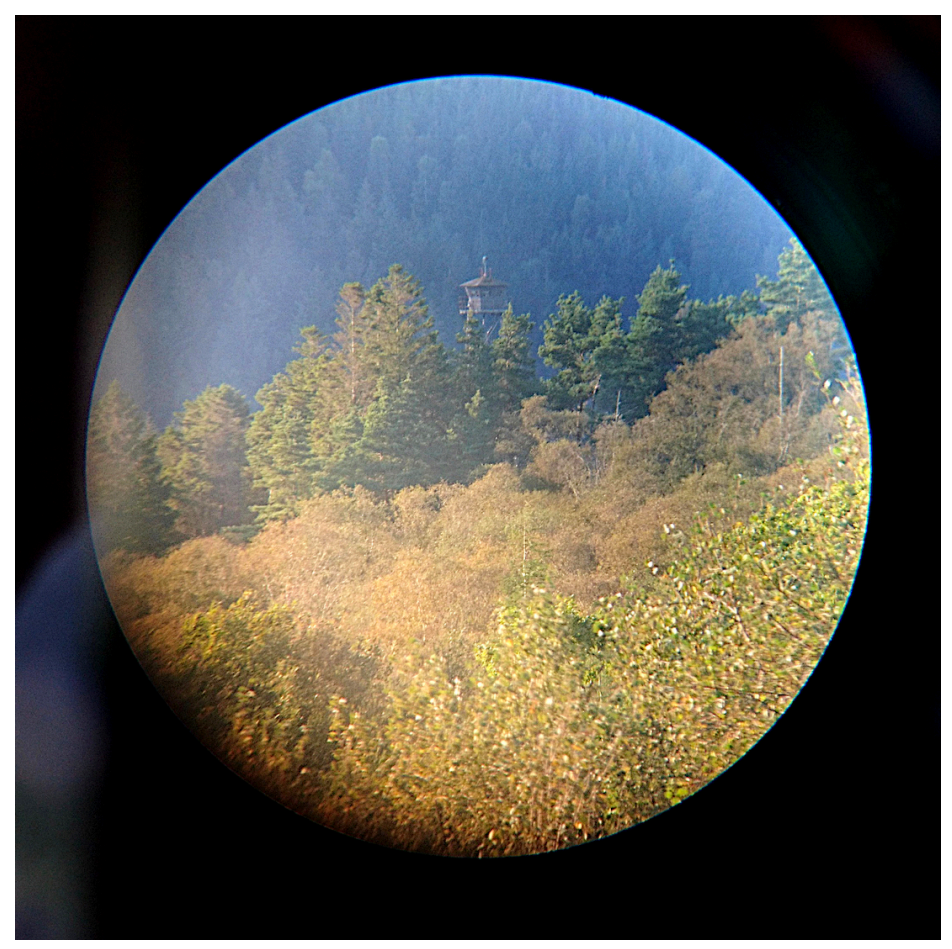

Figure 4. Watching the Watcher, 2019, B. D. Owens, digital photo $₫$ B. D. Owens.

The Gare Loch side and the loch water constitute a mostly publicly accessible space, even though there are significant restricted military zones. These restricted zones vary depending on the naval activity on the loch. People live in the old established villages and hamlets on the shoreline and 
hillsides next to, and on, Ministry of Defence land. I live in the hamlet settlement of Shandon, within walking distance of the Faslane Nuclear Submarine Base. Daily walking is a part of my art practice. In the Autumn of 2017, it occurred to me that when I walked along the loch shore I always headed south in the opposite direction of the Base and its malevolent fence. ${ }^{29,}{ }^{30}$ Who would want to wander under the watchful eye of surveillance cameras, next to rolls upon rolls of sinister razor wire and hostile security dog patrols? But even though I had been walking away from the Base, I began to observe a greater number of Ministry of Defence (MoD) police patrol cars. $^{31}$

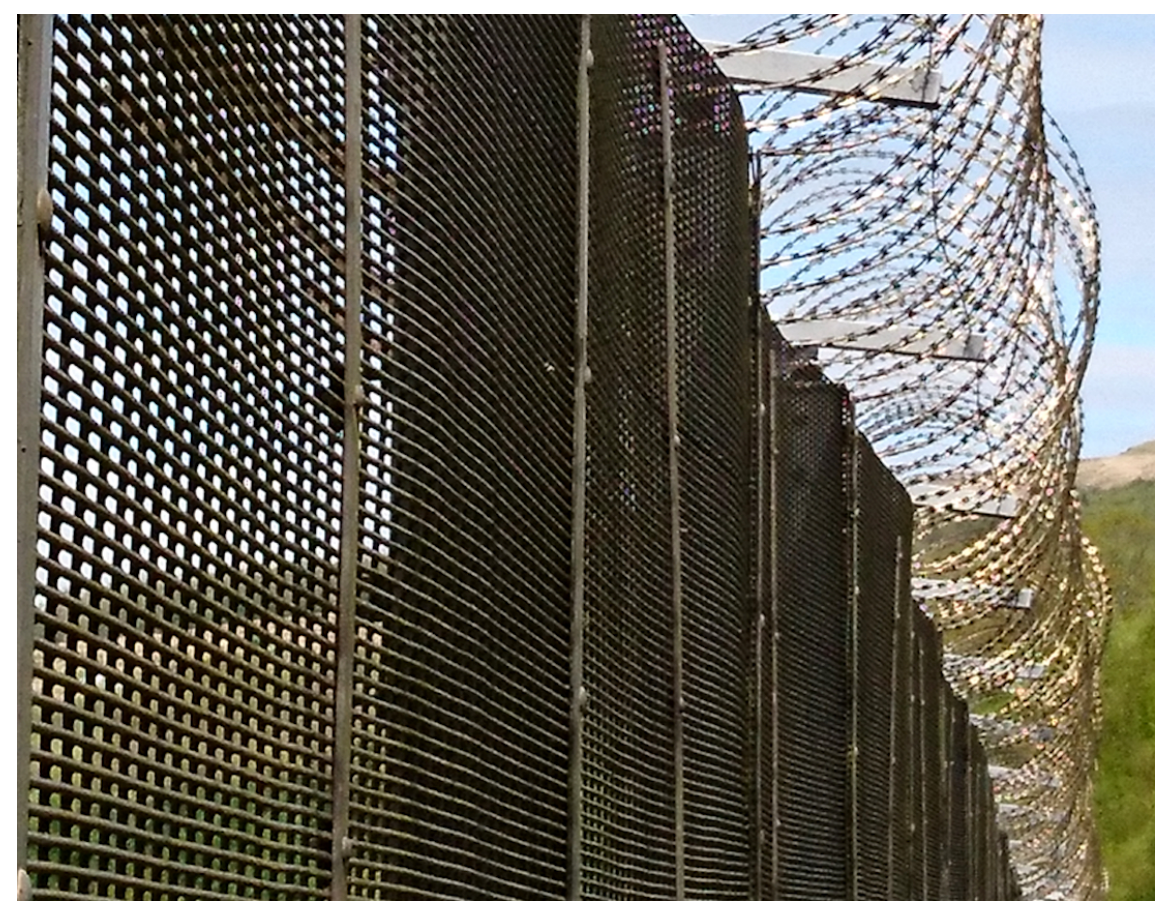

Figure 5. We Live with This Fence, 2018, B. D. Owens, digital photo (C B. D. Owens.

My mother and nephew had already been questioned by an intimidating MoD police officer with a machine gun; they were only sitting quietly on the beach, watching curlews, turn-stones, and oystercatchers. ${ }^{32,33}$ In another incident, six police officers came to search our garden because a neighbor called the police when they had seen someone suspicious on our lawn. ${ }^{34,}{ }^{35}$ It was me practicing slow dance movement. 


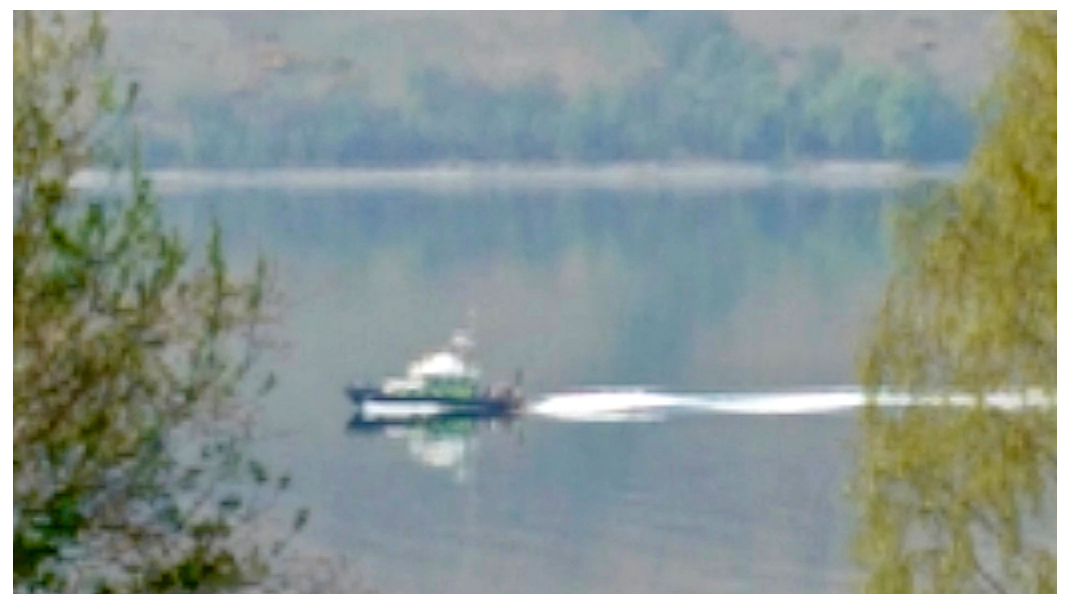

Figure 6. Dawn Chorus: Reflections Upon Surveillance, 2019, B. D. Owens, video still $@$ C B. D. Owens.

There also seemed to be an increasing presence of police boats surveilling the loch (and shore) at all hours of the day and night. ${ }^{36}$ Often the surveillance boats accompanied me on my walks only 100 meters or so from the shore, keeping in steady pace with my steps, marking a temporary white line on the surface of the dark water. ${ }^{37,38}$

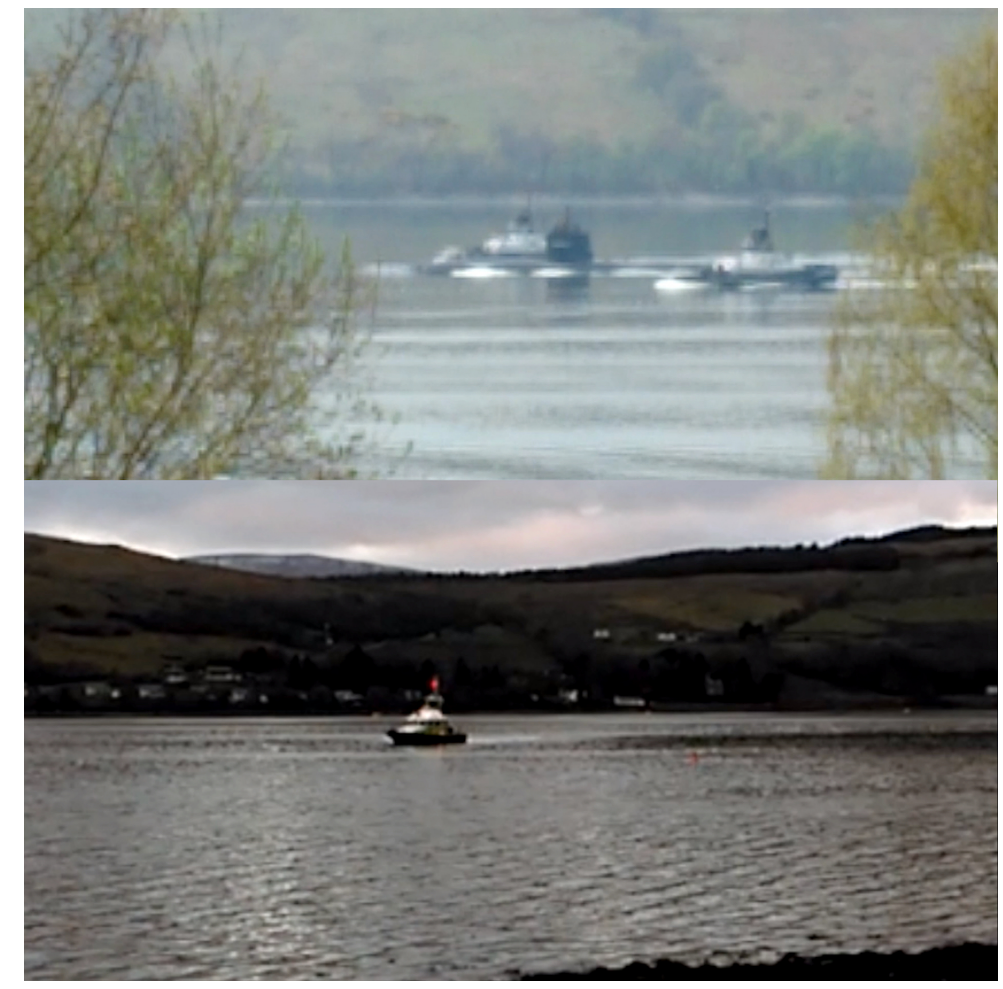

Figure 7. Watching Me, Watching You: Reflections Upon Surveillance, 2019, B. D. Owens, video stills $@$ B. D. Owens. 
In her essay "Nuclear Materiality" in The Nuclear Culture Source Book, curator Ele Carpenter asserts that "[t]he discourse on [nuclear] materiality has shifted [...] to physical and material concerns in which the public sphere is embedded politically, environmentally and psychologically." 39,40 Obviously, over the lifetime of the Base, the primary focus of dissent and protest has been towards the nuclear weapons and submarines that are housed at Faslane and Coulport. However, in my project, I am highlighting the broader "materiality" that maintains military "Nuclear Culture"; a Military Nuclear Occupation of a pre-existing peaceful ecosystem in the Gare Loch and Loch Long region. In addition to the nuclear submarines, the domineering fence, heavy constant surveillance, and the frequent military exercises on the loch (and hillsides) are all factors that broaden the military nuclear materiality. ${ }^{41}$ These factors contribute to ongoing psychological tension and division in the local community. The Faslane fence is more than a piece of architecture that divides the landscape.

\section{"...We live with this fence. We carry the fence with us, it cuts through all of our relationships. \#undesiredline \#walking \#fences \#lines \#durationalartwork"42}

There are many artists who have made lines through the process of durational performance. For example, Joseph DeLappe and Francis Alÿs have marked out lines along military-enforced mapped boundaries, whereas Ellie Harrison and Richard Long have made their intuitive travel lines visible. ${ }^{43,44,45,46}$ In his 2013 work Project 929: Mapping the Solar, Joseph DeLappe drew a continuous line, with a bicycle-mounted chalk stick, onto the road surface on the civilian side of the military-controlled perimeter that encircles the Nevada Test Site "Area 51" and Nellis Air Force Range. ${ }^{47}$ DeLappe re-mapped that area to highlight its superior alternative potential use as a massive solar farm. ${ }^{48}$ A few years earlier, in 2004, Francis Alÿs performed and painted The Green Line by dribbling green paint onto the ground as he walked the "Green Line" route, a militaryguarded stretch which partitions Jerusalem. ${ }^{49}$ The original partition line was drawn "with a green grease pencil" onto a map during the cease-fire agreement of $1948 .^{50}$ In 1967 UK, one year before the Faslane Base was opened, Richard Long made the artwork A Line Made by Walking. ${ }^{51} \mathrm{He}$ repeatedly tramped a straight pathway into long-ish grass in a field. ${ }^{52}$ Half a century later, artist Ellie Harrison used a GPS tracking device to mark the presence of her invisible travel lines. ${ }^{53}$ As part of her Glasgow Effect project Harrison created GPS "heatmap" illustrations with the downloaded device data to show the boundary line of the artwork and route lines that she made throughout $2016 .{ }^{54}$ When I walk, I do not electronically track my trajectory. Nevertheless, I have contributed to many networks of "desire lines" in rural and urban settings. ${ }^{55}$ Humans and animals make paths; mark territory with both conscious and unconscious desire.

\section{"In places, my traces are becoming a pathway. \#undesiredline \#walking \#pathway \#durationalartwork" ${ }^{956}$}

Spring 2018, I decided to push back and consciously mark out territory. ${ }^{57}$ I undertook a 224-mile pilgrimage over 50 days; a daily walk from the front door of my house to the front door of the Faslane Nuclear Submarine Base. ${ }^{58,59}$ A sustained, low-key disruption. It was a walking performance, through which I drew an Undesired Line on the grass verge in parallel to an existing "undesired line" - the perimeter fence of the Base. ${ }^{60,61,62}$ I claimed that stretch "of the fence as part of my sculpture." ${ }^{6364} 65$ Throughout the period of the performance/pilgrimage I kept a journal, collected field recordings, took a few sly photos and videos, had many interactions with the Ministry of Defence Police and made an online text-artwork using the Twitter hashtag, \#UndesiredLine. ${ }^{66,67,68}$ 


\section{"The spark of an arc beats a flashing pulse, where two lines are drawn too close. \#undesiredline \#fences \#lines \#walking \#listening",99}

While I walked the line, the fence was being transformed, the razor wire removed and new electric fence erected; the Cold War "look" replaced by a $21^{\text {st }}$-century facade. ${ }^{70,}{ }^{71}$ I made audio recordings of the clicking and buzzing sparks, deafening machine gun fire, loud speaker announcements and other soundscapes along the line of the Base perimeter. ${ }^{72}$ My digital audio recorder seemed to alarm the surveillance crews, and the military police were often dispatched to question me. I was up front that I was making an artwork, but I did not reveal that I was drawing a line. The patrols did regular drive-by observation, sometimes up to 12 times in a walk. I was questioned by the MoD police on most days, and I quickly became "known."73 As selfpreservation, I performed a cheery confidence, but that was difficult to maintain. To evade police questioning tactics, I tried to steer the conversations away from me and towards the nature surrounding the Base. The subject matter of this police small talk included: deer sightings, snowy owls, cuckoos and the dawn chorus. ${ }^{74,}{ }^{75}$ It was clear that the military police crews were very confused by our conversations, but perhaps entertained nonetheless.

\section{“Dragging one's feet is hard work \#undesiredline \#walking \#durationalartwork"76}

My early attempts at making a line with the "Richard Long technique" were scuppered, because MoD "vandals" obliterated my efforts with mowers. ${ }^{77,} 78$ So I switched technique to try to gouge deeper grooves. 7980 "I wore short-toothed urban crampons," but because I was dragging my feet, over time they snapped and I had to mend them several times with wire. ${ }^{81}$ With the dragging technique, I made parallel lines in the grass, which resembled cross-country ski tracks. ${ }^{82,83}$ It was a daily drag of discovery, documenting, observation, listening and reflection. My line marked the liminal zone between military occupation and civilian space. And although I was alone, I was making visible a line which had been trodden by thousands of peace-pilgrim-protesters over the previous 50 years. 


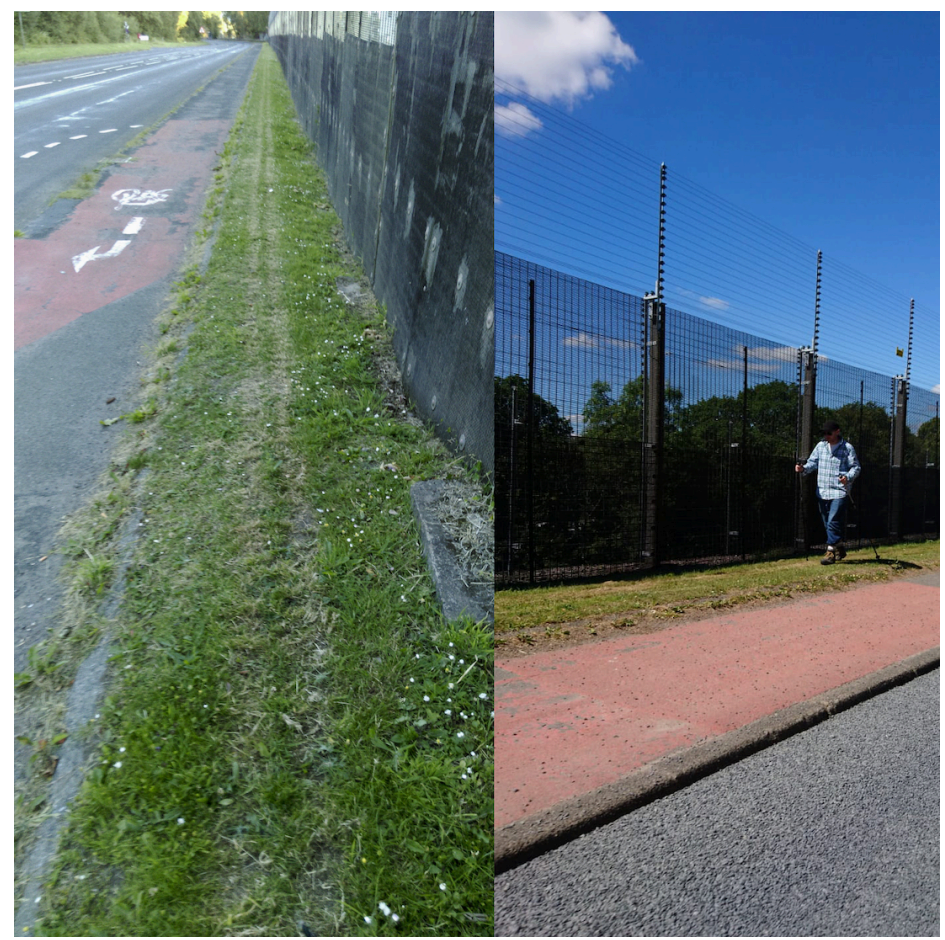

Figure 8. The Undesired Line, 2018, B. D. Owens, performance, Faslane fence \& parallel grooves in grass, digital photos $\mathbb{C}$ B. D. Owens.

In her book Wanderlust: A History of Walking, Rebecca Solnit recounts the time, during the 1980s, when she walked - and breached - the fence line of the Nevada Test Site, risking arrest along with other anti-nuclear peace protestors. ${ }^{84}$ "[They] bore a kind of bodily witness to [their] convictions, to the fierce beauty of the desert, and the apocalypses being prepared nearby." Unlike Solnit and her comrades, I neither breached, nor even touched the Faslane fence. I preferred my presence to be a persistent, prolonged and bewildering low-grade antagonism. The fact that I live in the neighborhood gave me an angle to defuse interactions with surveillance crews. ${ }^{86}$ I also dressed like a hill walker, and always wore the same black baseball cap so that I was easily recognized. And because I was making an artwork rather than an obvious protest, my presence was more accepted by the MoD police. In addition to these factors, I had the advantage of (and confidence in) Scotland's unusual legal framework. Scotland's Land Reform Act of 2003 (also known as "the freedom to roam" legislation) allows walkers/hikers to roam across public and private land in Scotland (within reason) ${ }^{87}$ Each temporary breach of the "undesired line" was a psychological one, through human-to-human in-person interaction with military surveillance personnel.

\section{Legacy of the \#UndesiredLine}

"Gare Loch duality. While the tide rises over the rocks, a heron peers patiently at the water, while a police boat surveils the shore. \#undesiredline \#heron \#surveillance» 88 
It was only when I observed the scene of heron and police boat (June 2018), that I realized the scope of the reading of duality. ${ }^{89}$ In Spring 2019, I reactivated the \#UndesiredLine hashtag on Twitter, in order to continue to observe and reflect upon the ongoing "Gare Loch duality." 90 The naval traffic along the loch, and most of the military exercises on the water, can be seen from my house or in the garden. I am continuing to make video clips, stills, tweets, poems and field recordings; piecing them together into narratives. I use a mobile phone camera to shoot video, pushing it further than its optical zoom in order to get a pixelated effect; referencing the look of older surveillance video. ${ }^{91}$ In contrast to the low-brow picture, I capture sound clips with a stereo digital recorder.

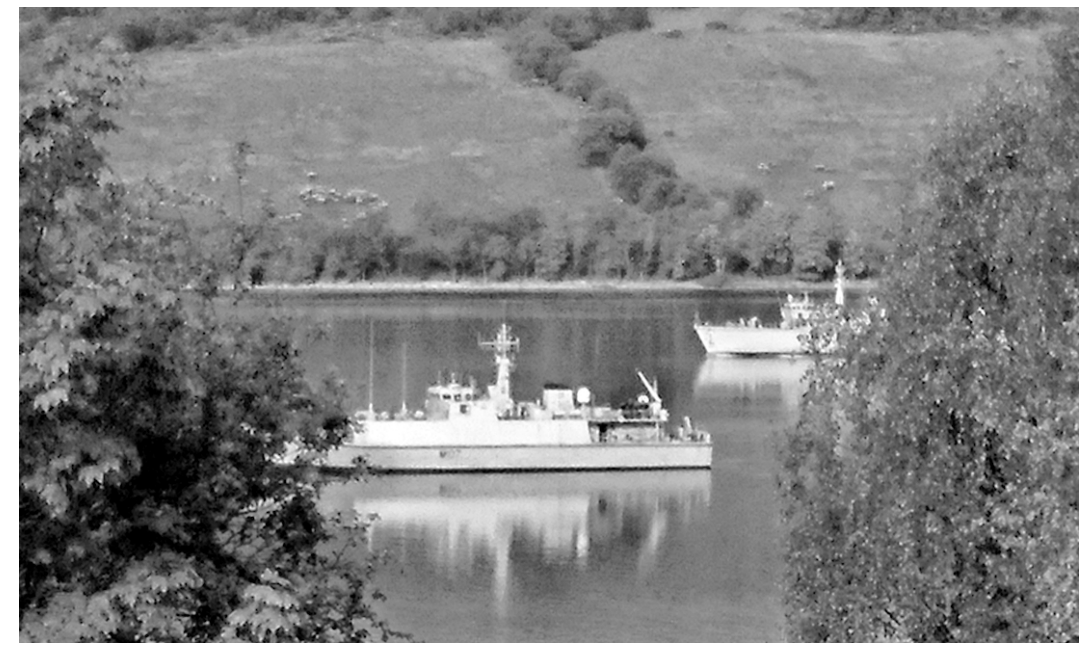

\section{Figure 9. Megaphone Wake Up, Saturday Morning 8am: Gare Loch Duality, 2019, B. D. Owens, video still C B. D. Owens}

By combining grainy visuals and clear sound, my aim is to bring attention to these textures. In the next stage of my project, I intend to position the individual narrative works into an interactive map artwork; a nautical chart of the Gare Loch rather than a land map. I had initially planned to make a video of a virtual walk along the Google Street View version of the "undesired" fence line, because the current Street View images are a historical document of the old Faslane fence from 2016. However, making a video of Google Street View breaks the Google user agreement. ${ }^{92}$ It is curious and frustrating that Google has been given the right to photograph the Base fence yet ordinary persons have been prohibited. Even though I am not allowed to make a video of the Street View images for public distribution, it makes sense to link this online artwork with specific Google Maps satellite images and some of the Google Street View vistas. ${ }^{93}$ But my nautical chart of the Gare Loch will not have GPS tagging throughout in order to protect the location of my house.

In addition to the pieces that I will embed in the mapping artwork, I have been making some intimate sculptures. Gare Loch Duality Jelly is an attempt to "preserve" the essence of the military and civilian activities which took place on the loch shore and on the water in that particular moment in time. ${ }^{94}$ I gifted these jars of jelly to some of the viewers who had been 
interacting with the Twitter hashtag \#UndesiredLine, as well as one lucky audience member who won a jar at the NEoN Festival Re@ct: Social Change Art Technology Symposium.

"Gare Loch apples, crab apples \& rowan berries boiled and strained and boiled again with fair-trade sugar and pectin. Jars of sweet amber set to a soundtrack of megaphones and machine guns. Gare Loch duality and the \#undesiredline"95

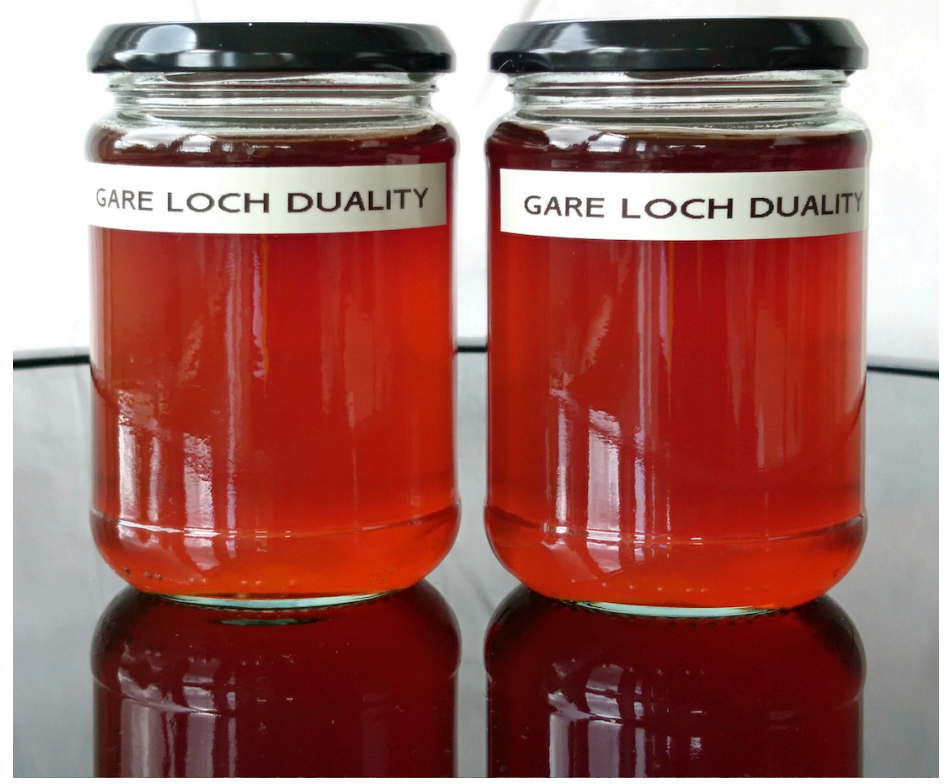

Figure 10. Gare Loch Duality Jelly, 2019, B. D. Owens, fruit preserve in glass jars, text labels $\subset$ B. D. Owens

This multilayered, hybrid artwork would have been less versatile had I not had the opportunity to use Twitter to host the \#UndesiredLine textwork. The textwork of tweets in the hashtag were the only documentation that I felt I could risk releasing publicly while making the pilgrimage performance. As a result, the tweets became the spine of the broader project. There are several advantages to piggy-backing an artwork onto an existing online platform such as Twitter. Twitter provides immediate access (including disability access) for an international audience to view and interact with the work, but the viewer has no need to sign up to a Twitter account in order to see tweets and hashtag pages. When using a Twitter hashtag, the tweets are contained together. As a consequence, one can gradually reveal the textwork in incremental episodes over time; this has the potential to keep the viewer/reader engaged.

Twitter, however, is not a panacea. Generally, I find tweeting really stressful because mistakes cannot be edited, every tweet is a kind of performance. There are some other downsides to hosting the \#UndesiredLine on Twitter. Given the high likelihood that the military are surveilling 
my online communications, there is a significant potential for censorship. There is also the ubiquitous problem of trolls, bots and vandals that could ruin the project. More importantly, in purely practical terms, all digital platforms are precarious; for example, Twitter comments can disappear if users close their accounts or delete tweets. I admit that using Twitter to host an artwork is questionable; it is well established that Twitter is designed to "use the user" for "data mining." 96 Nevertheless, I see my project as an intervention. I am "using" Twitter back, claiming territory, taking up room in hashtag space with a textwork that is not particularly useful to "surveillance capitalism." ${ }^{.97}$ I encourage people to view the hashtag without logging in to Twitter, unless they wish to interact with the tweets. This will reduce some of the potential for data mining in relation to this project, with the exception of browser data and cookie collection.

Throughout my multi-disciplinary practice, I aim to "examine and challenge binary, polarized doctrines and ideological positions, [with an attempt] to reveal nuances and complexities that may shift set-thinking and preconceptions." "98 My hope is that this will encourage dialogue. In some ways the tentative beginnings of dialogue have already appeared within Gare Loch Duality and the \#Undesired Line. A number of one-to-one conversations with other locals have been made possible, because the artwork has offered an opportunity for people to open up and reveal what they think.

Donna Haraway attests that when attempting to broach polarized subject matter,

there is a strategic use to speaking the same idiom as the people that you are sharing the room with. You craft a good-enough idiom so you can work on something together. I go with what we can make happen in the room together. And then we go further tomorrow. ${ }^{99,} 100$

People in this locality all share the common experience of intrusive military surveillance, and we all have the challenging task of navigating the "the fence" in our daily lives. Hopefully the Gare Loch Duality and the \#UndesiredLine artwork holds broad enough elements of interest and reflection to draw people "[into] the room together [so we can] go further tomorrow."101, 102

\section{ACKNOWLEDGEMENTS}

Thank you to David Rokeby, Janet Cardiff and Bill Brown (Surveillance Camera Players) for granting permission to use images. Thank you to the NEoN curatorial team.

\section{ENDNOTES}

1. Steven Brocklehurst, "Life in Faslane: 50 Years of Nuclear Submarines on the Clyde," BBC Scotland News, May 10, 2018, https://www.bbc.co.uk/news/uk-scotland-43975011 One thing to consider about this article: there is a false (yet dominant) narrative in the media that there were no civilian activities (or settlements) on the site of the Faslane Base before (or after) the British Royal Navy arrived. I challenge this false narrative and examine some of the $19^{\text {th }}$-century and $20^{\text {th }}$-century civilian history in my video Gare Loch Duality and the \#UndesiredLine, 2020. 
2. Andy Wightman, The Poor Had No Lawyers: Who Owns Scotland (And How They Got It), (Edinburgh: Birlinn, 2015), 149.

3. "Garelochhead, Coulport, Glen Douglas \& Faslane," Property Map, Who Owns Scotland, accessed May 12, 2020, http://www.whoownsscotland.org.uk/property.php?p=5859

4. B. D. Owens and Ana Hine, "Talking About Walking the \#UndesiredLine," NEoN, September

4, 2020, https://northeastofnorth.com/talking-about-walking-the-undesiredline/

5. Ibid.

6. B. D. Owens, "Gare Loch Duality and the \#UndesiredLine," presented by NEoN Digital Arts, UK Garden, Ars Electronica Festival 2020, September 11, 2020, video, 25:00.

7. Brett Frischmann and Evan Selinger, Re-Engineering Humanity, (Cambridge: Cambridge University Press, 2018), 20, 21, 37.

8. Clive Norris, Mike McCahill and David Wood, "The Growth of CCTV: A Global Perspective on the International Diffusion of Video Surveillance in Publicly Accessible Space," CCTV Special, Surveillance \& Society, Vol 2, no. 2/3 (2004): 113-115,

https://doi.org/10.24908/ss.v2i2/3.3369

9. "History of NIJ Support for Face Recognition Technology," National Institute of Justice, last modified March, 2020, https://nij.ojp.gov/topics/articles/history-nij-support-face-recognitiontechnology

10. "Interactive Installations: Taken (2002)," David Rokeby Web Site, accessed April, 10, 2018, http://www.davidrokeby.com/taken.html

11. Ibid.

12. Ibid.

13. Ibid.

14. Hille Koskela "“The Gaze Without Eyes': Video-Surveillance and the Changing Nature of Urban Space," Progress in Human Geography, Vol 24, no. 2 (2000): 243-265.

15. David Rokeby, "The Construction of Experience: Interface as Content," Digital Illusion: Entertaining the Future with High Technology, ed. Clark Dodsworth (ACM Addison-Wesley Publishing Company, 1998), http://www.davidrokeby.com/experience.html 16. Elaine Tolmatch and Dina Vescio, Case Study, "Janet Cardiff, Eyes of Laura, 2004," Documentation and Conservation of the Media Arts Heritage, accessed April, 10, 2018, https://www.docam.ca/en/case-studies/eyes-of-laura-j-cardiff.html

17. Ibid.

18. Ibid.

19. Ibid.

20. Erich W. Schienke and Bill Brown, "Streets into Stages: An Interview with Surveillance Camera Players' Bill Brown" Surveillance \& Society, Vol 1, no. 3 (2003): 356-374, https://doi.org/10.24908/ss.vli3.3345

21. Tyee Bridge, "Glossary//Surveillance Camera Players," Adbusters: Journal of the Mental Environment, Vol 10, no. 2 (2002): 96, https://archive.org/details/adbusters 40/page/n95

22. Schienke and Brown, "Streets into Stages," 356-374.

23. Darren Ellis, Dave Harper and Ian Tucker, "Experiencing the Surveillance Society," The Psychologist: The British Psychological Society, Vol 29 (2016): 682-685, https://thepsychologist.bps.org.uk/volume-29/september/experiencing-surveillance-society 24. Hille Koskela, “'Cam Era' - The Contemporary Urban Panopticon," Surveillance \& Society, Vol 1, no. 3 (2003): 292-313, https://doi.org/10.24908/ss.v1i3.3342

25. Ellis, Harper and Tucker, "Experiencing the Surveillance Society," 682-685. 
26. Kaleigh Rogers, "What Constant Surveillance Does to Your Brain," Vice, Motherboard, November 14, 2018, https://www.vice.com/en_us/article/pa5d9g/what-constant-surveillancedoes-to-your-brain

27. Ewen MacAskill, Gabriel Dance, Fielding Cage and Greg Chen, "NSA FILES: DECODED," The Guardian, November 1, 2013,

https:/www.theguardian.com/world/interactive/2013/nov/01/snowden-nsa-files-surveillancerevelations-decoded\#section/1

28. Ellis, Harper and Tucker, "Experiencing the Surveillance Society," 682-685.

29. Owens, "Gare Loch Duality and the \#UndesiredLine."

30. Owens and Hine, "Talking About Walking."

31. Rob Edwards "Fears over Expanding MoD Police Role on the Clyde," The Ferret, September 1, 2017, https://theferret.scot/fears-expanding-mod-police-role-clyde/

32. Owens, "Gare Loch Duality and the \#UndesiredLine."

33. Owens and Hine, "Talking About Walking."

34. Ibid.

35. Owens, "Gare Loch Duality and the \#UndesiredLine."

36. Ibid.

37. Ibid.

38. B. D. Owens, "Psychological Impacts of Surveillance: Within the Context of Gare Loch Duality and the \#UndesiredLine," presented by NEoN Digital Arts, UK Garden, Ars Electronica Festival 2020, September 11, 2020, video, 30:00. Video content: B. D. Owens, in conversation with Professor David Harper and Dr. Darren Ellis (University of East London).

39. Ele Carpenter, "Nuclear Materiality: Introduction," in The Nuclear Culture Source Book, ed. Ele Carpenter (London: Black Dog Publishing, 2016), 48-49.

40. Owens, "Gare Loch Duality and the \#UndesiredLine."

41. Ibid.

42. B. D. Owens (@B_D_Owens). 2020.“...We live with this fence. We carry the fence with us, it cuts through all of our relationships. \#undesiredline \#walking \#lines \#fences

\#durationalartwork." Twitter, July 10, 2018, 10:21p.m.

https://witter.com/B D OWENS/status/1016794448074854402

43. Joseph DeLappe, "Project 929 Mapping the Solar - Art Intervention at the Nellis Air Force Range," videography Laurie Macfee, editor Dillon McGillivray, USA, 2013, video, 03:46.

http://www.delappe.net/intervene/project-929-mapping-the-solar/

44. "The Green Line (2004)," Francis Alÿs Web Site, accessed July, 20, 2021

https://francisalys.com/the-green-line/

45. Ellie Harrison, The Glasgow Effect: A Tale of class, capitalism and carbon footprint, (Edinburgh: Luath Press, 2019), 244-245.

46. Tim Ingold, Lines: A Brief History, (London: Routledge, 2016), 44.

47. DeLappe, "Project 929 Mapping the Solar," video.

48. "Project 929: Mapping the Solar (2013)," Joseph DeLappe Web Site, accessed July, 20, 2021 http://www.delappe.net/intervene/project-929-mapping-the-solar/

49. Alÿs Web Site, "The Green Line."

50. Francis Alÿs, "The Green Line," in collaboration with Philippe Bellaiche, Rachel Leah Jones and Julien Devaux, Jerusalem, Israel, 2004, video, 17:41. https://francisalys.com/the-green-line/ 51. Ingold, Lines, 44.

52. Ibid.

53. Harrison, The Glasgow Effect, 138. 
54. Harrison, The Glasgow Effect, 244-245.

55. Ellie Violet Bramley, "Desire Paths: The Illicit Trails That Defy the Urban Planners," The Guardian, October 5, 2018, https://www.theguardian.com/cities/2018/oct/05/desire-paths-theillicit-trails-that-defy-the-urban-planners

56. B. D. Owens (@B_D_Owens).2020. “In places, my traces are becoming a pathway. \#undesiredline \#walking \#pathway \#durationalartwork.” Twitter, May 23, 2018, 10:58 p.m. https://twitter.com/B D OWENS/status/999409231777411072

57. Owens and Hine, "Talking About Walking."

58. Ibid.

59. Owens, "Gare Loch Duality and the \#UndesiredLine.".

60. Ibid.

61. Owens and Hine, "Talking About Walking."

62. B. D. Owens (@B_D_Owens).2020. "The act of drawing/dragging a line with my body in the grass \& earth next to the Faslane fence, on a 50-day daily pilgrimage and claiming that section of the fence as part of 'my sculpture', are acts of resistance... \#undesiredline \#walking \#fences \#durationalartwork." Twitter, July 10, 2018, 10:17 p.m.

https://twitter.com/B D OWENS/status/1016793623436898304

63. Ibid.

64. Owens and Hine, "Talking About Walking."

65. Owens, "Gare Loch Duality and the \#UndesiredLine."

66. Ibid.

67. B. D. Owens and Donna Holford-Lovell, "Gare Loch Duality and the \#UndesiredLine Q\&A," Q\&A hosted by Donna Holford-Lovell, presented NEoN Digital Arts, UK Garden, Ars

Electronica Festival 2020, September 11, 2020, video, 30:00.

68. Owens and Hine, "Talking About Walking."

69. B. D. Owens (@B_D_Owens).2020. “The spark of an arc beats a flashing pulse, where two lines are drawn too close. \#undesiredline \#fences \#lines \#walking \#listening." Twitter, June 10, 2018, 10:51 p.m. https://twitter.com/B D OWENS/status/1005930459640029191

70. B. D. Owens (@B_D_Owens). 2020. “The $21^{\text {st }}$ Century facelift continues. Rolls of 1980s Cold War razor wire shed day by day. New electric fence wires are threaded through thousands of insulation grommets, a dainty needlework for macho men. \#undesiredline \#fences \#boundaries \#borders." Twitter, June 12, 2018, 11:41 p.m.

https://twitter.com/B D OWENS/status/1006667728734904320

71. Owens, "Gare Loch Duality and the \#UndesiredLine."

72. Ibid.

73. Owens and Holford-Lovell, "\#UndesiredLine Q\&A."

74. B. D. Owens (@B_D_Owens).2020. “Subject matter of yesterday’s MoD police small talk: snowy owls, cuckoos and dawn chorus \#undesiredline \#durationalartwork \#birds," Twitter, June 10, 2018, 3:24 p.m. https://twitter.com/B D OWENS/status/1005817930431520768

75. Owens, "Gare Loch Duality and the \#UndesiredLine."

76. B. D. Owens (@B_D_Owens).2020. “Dragging one's feet is hard work \#undesiredline \#walking \#durationalartwork." Twitter, June 6, 2018, 10:42 p.m.

https://twitter.com/B D OWENS/status/1004478576484405248

77. Owens and Hine, "Talking About Walking."

78. B. D. Owens (@B_D_Owens).2020. "I had made a beautiful line, it even had 3 lovely curves that followed the terrain of the grass verge, but the mower shredded it on day 18. Vandals. \#undesiredline \#walking \#durationalartwork," Twitter, June 5, 2018, 9:07 p.m.

https://witter.com/B D OWENS/status/1004092423860113411 
79. B. D. Owens (@B_D_Owens).2020. “Since I am a sculptor, I have decided to use tools attached to my feet, metal teeth. I am carving a path, a groove, with my body. Drawing a line in the earth. \#undesiredline \#walking \#durationalartwork," Twitter, June 10, 2018, 3:58 p.m. https://twitter.com/B D OWENS/status/1005826454033182720

80. Owens and Hine, "Talking About Walking."

81. Ibid.

82. B. D. Owens (@B_D_Owens).2020. “My line has become 2 parallel lines along some stretches, like dark green cross-country ski tracks. \#undesiredline \#walking \#durationalartwork," Twitter, June 6, 2018, 10:53 p.m.

https://twitter.com/B D OWENS/status/1004481330376314880

83. Owens and Hine, "Talking About Walking."

84. Rebecca Solnit, Wanderlust: A History of Walking, (London: Granta, 2014), 7.

85. Solnit, Wanderlust, 8.

86. Owens and Holford-Lovell, "\#UndesiredLine Q\&A."

87. "Statutory Access Rights," Scottish Rights of Way \& Access Society, accessed April 10, 2020, https://www.scotways.com/faq/law-on-statutory-access-rights

88. B. D. Owens (@B_D_Owens).2020. "Gare Loch duality. While the tide rises over the rocks, a heron peers patiently at the water, while a police boat surveils the shore. \#undesiredLine \#heron \#surveillance." Twitter, June 23, 2018, 11:16 p.m.

https://twitter.com/B_D_OWENS/status/1010647759114956800

89. Owens, "Gare Loch Duality and the \#UndesiredLine."

90. Owens and Hine, "Talking About Walking."

91. Owens, "Gare Loch Duality and the \#UndesiredLine."

92. “Google Maps \& Google Earth: General Guidelines,” Permissions, Google, accessed July 10, 2020, https://www.google.com/permissions/geoguidelines/

93. "Faslane Fence, A814,” Google Street View, accessed July 24, 2020,

https://www.google.co.uk/maps/@,56.0622582,4.8135904,3a,75y,342.83h,90t/data=!3m6!1e1!3m 4!1sckTI6g08Qo3fz4uDoMC81Q!2e0!7i13312!8i6656

94. Food as sculpture has long been part of my art practice. However, this is the first time I have shared food with an audience.

95. B. D. Owens (@B_D_Owens). 2020. “Gare Loch apples, crab apples \& rowan berries boiled and strained and boiled again with fair-trade sugar and pectin. Jars of sweet amber set to a soundtrack of megaphones and machine guns. Gare Loch duality and the \#undesiredline."

Twitter, October 12, 2019, 11:37 a.m.

https://twitter.com/B D OWENS/status/1182968442502209536

96. Juliette Garside, "Twitter Puts Trillions of Tweets Up for Sale to Data Miners," The

Guardian, March 18, 2015, https://www.theguardian.com/technology/2015/mar/18/twitter-putstrillions-tweets-for-sale-data-miners

97. Frischmann and Selinger, Re-Engineering Humanity, 116. Frischmann and Selinger explain "surveillance capitalism", a term "coined" by Shoshana Zuboff.

98. "Statement of Practice,” B. D. Owens Web Site, accessed July 10, 2020,

http://bdowens.co.uk/about

99. Moira Weigel, "Feminist Cyborg Scholar Donna Haraway: The Disorder of Our Era Isn't Necessary," The Guardian, June 20, 2019,

https://www.theguardian.com/world/2019/jun/20/donna-haraway-interview-cyborg-manifestopost-truth?CMP $=$ share btn tw

100. Owens and Holford-Lovell, "\#UndesiredLine Q\&A." 
101. Weigel, "Feminist Cyborg Scholar."

102. Owens and Holford-Lovell, "\#UndesiredLine Q\&A."

\section{REFERENCES}

Alÿs, Francis. "The Green Line.” In collaboration with Philippe Bellaiche, Rachel Leah Jones and Julien Devaux. Jerusalem, Israel, 2004. Video, 17:41. https://francisalys.com/the-green-line/

Bramley, Ellie Violet. "Desire Paths: The Illicit Trails That Defy the Urban Planners." The Guardian, October 5, 2018. https:/www.theguardian.com/cities/2018/oct/05/desire-paths-the-illicit-trailsthat-defy-the-urban-planners

Bridge, Tyee. "Glossary//Surveillance Camera Players," Adbusters: Journal Of The Mental Environment Vol 10, no. 2 (2002): 96. https://archive.org/details/adbusters 40/page/n95

Brocklehurst, Steven. "Life in Faslane: 50 years of Nuclear Submarines on the Clyde.” $B B C$ Scotland News, May 10, 2018. https://www.bbc.co.uk/news/uk-scotland-43975011

Carpenter, Ele. "Nuclear Materiality: Introduction," In The Nuclear Culture Source Book, edited by Ele Carpenter, 48 - 49. London: black dog publishing, 2016.

DeLappe, Joseph. "Project 929 Mapping the Solar - Art Intervention at the Nellis Air Force Range.” Videography Laurie Macfee, editor Dillon McGillivray. USA, 2013. Video, 03:46. http://www.delappe.net/intervene/project-929-mapping-the-solar/

Edwards, Rob. "Fears over Expanding MoD Police Role on the Clyde." The Ferret, September 1, 2017. https://theferret.scot/fears-expanding-mod-police-role-clyde/

Ellis, Darren, Dave Harper and Ian Tucker. "Experiencing the Surveillance Society." The Psychologist: The British Psychological Society Vol 29 (2016): 682-685.

https://hepsychologist.bps.org.uk/volume-29/september/experiencing-surveillance-society

Frischmann, Brett and Evan Selinger. Re-Engineering Humanity. Cambridge: Cambridge University Press, 2018.

Garside, Juliette. "Twitter Puts Trillions of Tweets Up for Sale to Data Miners." The Guardian, March 18, 2015. https://www.theguardian.com/technology/2015/mar/18/twitter-puts-trillionstweets-for-sale-data-miners

Google. "Google Maps \& Google Earth: General Guidelines.” Permissions. Accessed July 10, 2020. https://www.google.com/permissions/geoguidelines/

Google Street View. "Faslane Fence, A814.” Accessed July 24, 2020.

https://www.google.co.uk/maps/@,56.0622582,-

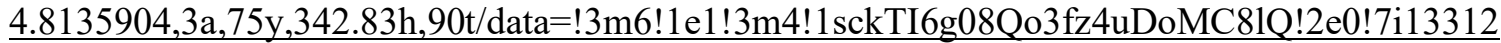
$\underline{! 8 \mathrm{i} 6656}$ 
Harrison, Ellie. The Glasgow Effect: A Tale of Class, Capitalism and Carbon Footprint.

Edinburgh: Luath Press, 2019.

Ingold, Tim. Lines: A Brief History. London: Routledge, 2016.

Koskela, Hille. "“Cam Era' - The Contemporary Urban Panopticon.” Surveillance \& Society Vol 1, no. 3 (2003): 292-313. https://doi.org/10.24908/ss.v1i3.3342

Koskela, Hille. "'The Gaze Without Eyes': Video-Surveillance and the Changing Nature of Urban Space." Progress in Human Geography Vol 24, no. 2 (2000): 243-265.

https://doi.org/10.1191/030913200668791096

MacAskill, Ewen, Gabriel Dance, Fielding Cage and Greg Chen. "NSA FILES: DECODED." The Guardian, November 1, 2013.

https:/www.theguardian.com/world/interactive/2013/nov/01/snowden-nsa-files-surveillance$\underline{\text { revelations-decoded\#section/1 }}$

National Institute of Justice. "History of NIJ Support for Face Recognition Technology." March 5, 2020. https://nij.ojp.gov/topics/articles/history-nij-support-face-recognition-technology

Norris, Clive, Mike McCahill and David Wood. "The Growth of CCTV: A Global Perspective on the International Diffusion of Video Surveillance in Publicly Accessible Space." Surveillance \& Society Vol 2, no. 2/3 (2004): 113-115. https://doi.org/10.24908/ss.v2i2/3.3369

Owens, B. D. "Gare Loch Duality and the \#UndesiredLine.” Presented by NEoN Digital Arts, UK Garden, Ars Electronica Festival 2020. September 11, 2020. Video, 25:00.

Owens, B. D. "Psychological Impacts of Surveillance: Within the Context of Gare Loch Duality and the \#UndesiredLine." Presented by NEoN Digital Arts, UK Garden, Ars Electronica Festival 2020. September 11, 2020. Video, 30:00.

Owens, B. D. “Statement of Practice.” Accessed July 10, 2020. http://bdowens.co.uk/about

Owens, B. D. and Ana Hine. "Talking About Walking the \#UndesiredLine." NEoN, September 4, 2020. https://northeastofnorth.com/talking-about-walking-the-undesiredline/

Owens, B. D. and Donna Holford-Lovell. "Gare Loch Duality and the \#UndesiredLine Q\&A." Q\&A hosted by Donna Holford-Lovell. Presented NEoN Digital Arts, UK Garden, Ars Electronica Festival 2020. September 11, 2020. Video, 30:00.

Rogers, Kaleigh. "What Constant Surveillance Does to Your Brain." Vice, Motherboard, November 14, 2018. https://www.vice.com/en_us/article/pa5d9g/what-constant-surveillancedoes-to-your-brain

Rokeby, David. "The Construction of Experience: Interface as Content." In Digital Illusion: Entertaining the Future with High Technology, edited by Clark Dodsworth. ACM AddisonWesley Publishing Company, 1998. http://www.davidrokeby.com/experience.html 
Rokeby, David. "Interactive Installations: Taken (2002)." Accessed April 10, 2018.

http://www.davidrokeby.com/taken.html

Schienke, Erich W. and Bill Brown. "Streets into Stages: An Interview with Surveillance Camera Players' Bill Brown." Surveillance \& Society Vol 1, no. 3 (2003): 356-374.

https://doi.org/10.24908/ss.v1i3.3345

Scottish Rights of Way \& Access Society. "Statutory Access Rights." Accessed April 10, 2020. https://www.scotways.com/faq/law-on-statutory-access-rights

Solnit, Rebecca. Wanderlust: A History of Walking. London: Granta, 2014.

Tolmatch, Elaine and Dina Vescio. "Janet Cardiff, Eyes of Laura, 2004.” Case Studies. Documentation and Conservation of the Media Arts Heritage. Accessed April, 10, 2018. https://www.docam.ca/en/case-studies/eyes-of-laura-j-cardiff.html

Twitter. "\#UndesiredLine.” Accessed October 10, 2020. https://twitter.com/hashtag/undesiredline? $\mathrm{src}=$ hash\&f=live

Weigel, Moira. "Feminist Cyborg Scholar Donna Haraway: The Disorder of Our Era Isn't Necessary." The Guardian, June 20, 2019.

https://www.theguardian.com/world/2019/jun/20/donna-haraway-interview-cyborg-manifestopost-truth?CMP=share btn tw

Who Owns Scotland. "Garelochhead, Coulport, Glen Douglas \& Faslane.” Accessed May 12, 2020. http://www.whoownsscotland.org.uk/property.php? $\mathrm{p}=5859$

Wightman, Andy. The Poor Had No Lawyers: Who Owns Scotland (And How They Got It). Edinburgh: Birlinn, 2015.

\section{AUTHOR BIO}

B. D. Owens is a multi-disciplinary artist based in Shandon, on the Gare Loch, Scotland. Owens holds an MFA in Art, Society \& Publics from DJCAD, University of Dundee, and a BFA in Sculpture from Concordia University (Montreal). His writing has been published in two anthologies-We Were Always Here: A Queer Words Anthology and Talking About Lobsters: New Writing Scotland Issue 34-as well as on the eco/art/scot/land artist research blog. Since 2012, he has shown his artwork in Canada, USA, Scotland, Germany and online. In 2020, NEoN presented two of his videos in the UK Garden at Ars Electronica Festival 2020.

www.bdowens.co.uk 
